Sanja Mrazovac Kurilić ${ }^{1}$

Faculty of ecology and environmental protection, University "Union-Nikola Tesla"

Khalil Salem Abulsba ${ }^{2}$

Al-Mergeb University

\section{Svetlana Roljević Nikolić3}

Institute of Agricultural Economics Belgrade
P. 13-19

ORIGINAL SCIENTIFIC ARTICLE doi:10.5937/ESD1902013M

Received: October, 17, 2019

Accepted: December, 01, 2019

\title{
APPLICATION OF MATHEMATICAL MODELING IN ECOLOGY ${ }^{4}$
}

\begin{abstract}
The aim of this paper was implementation of mathematical modeling in ecological research on the example of the prevalence of odonates in Serbia. For research purposes cix areas were selected for which the number of species of odonants was given, a similarity coefficient was calculated, and based on the data as the number of species and environmental variables of the place (altitude, temperature and precipitation), multiple linear regression (MLR) model was presented describing the number of species odonants depending on altitude, temperature and precipitation. The areas studied were the rivers Tisa, Sava-Danube, Velika Morava, Južna Morava, as well as the mountain areas Zlatibor and Golija. The occurrence of the species was highest at the Sava-Danube site, followed by the Tisa. Odonates occurrence was lowest in the Golija site. The results of the study showed that environmental variables are significantly associated with odonates distribution. The MLR model based on the species dependence of altitude, temperature, and precipitation showed an extremely high degree of agreement.
\end{abstract}

Key words: Mathematical modeling, MLR, environmental factors

JEL classification: C0, C1,Q54

\section{ПРИМЕНА МАТЕМАТИЧКОГ МОДЕЛОВАҢА У ЕКОЛОГИЈИ}

\section{Апстракт}

Циљь рада је примена математичког моделираға у еколошким истраживанима на примеру распространености одонаната у Србији. За потребе истраживана

\footnotetext{
${ }^{1}$ mrazovac@gmail.com

2abulsba73@yahoo.com

${ }^{3}$ svetlana_r@iep.bg.ac.rs

${ }^{4}$ Paper is part of the project III 46006 "Sustainable agriculture and rural development in function of Republic of Serbia strategic goals achievement within the Danube region" financed by the Ministry of Education, Science and Technological Development, period 2011-2019
} 
одабрано је шест подручја за која је дат број врста одонаната, затим је израчунат коебииијент сличности а на основу података о броју врста и чинилача сполашюе средине (надморска висина, температура и падавине), док је моделом вишеструке тинеарне регресије (МЛР ) представльен број врста одонаната врста у зависности од надморске висине, температуре и падавина. Проучавана подручја били су речни токови Тисе, Сава-Дунав, Велике Мораве, Јужне Мораве, као и планинска подручја Златибора и Голије. Број врста био је највећи на месту Сава-Дунав, а затим на подручју Тисе. Појава одоната била је најмаға на подручју места Голије. Резултати истраживана су показали да су променғиви чиниоци животне средине значајно повезани са дистрибуичјом одоната. Модел МЛР заснован на зависностима од висине, температуре и падавина показао је изузетно висок степен слагана.

Ključne reči: Математичко моделоване, $M L R$, еколочки чиниоци

\section{Introduction}

In the field of ecology, scientists are confronted with the dynamics of nature, in terms of population growth or decline in a large number of plant and animal species. Given the strong influence of man and nature and the entire living world, it is necessary to apply mathematical models that will evaluate the impact of the environment on a population of some species. Knowledge about the environmental impact on living organisms may contribute to their preservation (Suhling et al., 2006).

Species are not similarly distributed across the Earth. The serious decrease in species number (Chapin et al. 2000) increased the urgency to understand species distribution in order to develop effective conservation strategies (Robinet et al. 2019; Franzese et al. 2019). An understanding of the relationship between species and the environment is of great importance (Williams et al., 2002).

The utilization of insect as bioindicators is limited to their habitat type (McGeoch, 1998). The odonates are freshwater invertebrates and are often used as ecological indicators of habitat quality (Hardersen, 2000; Sahlen and Ekestubbe, 2001; Silva et al., 2010; Arimoro et al., 2011; Simaika and Samways, 2011). Some studies (Samways and Steytler, 1996; Oppel, 2006; Silva et al., 2010) have pointed out that odonates may serve as an indicator for changes in landscapes. But, their reaction to environmental conditions in numerous areas of the world is unknown (Bried and Mazzacano, 2010; Clausnitzer et al., 2012). Knowledge about the environmental impact on odonates may contribute to their preservation (Sahlen and Ekestubbe, 2001; Suhling et al., 2006).

A substantial number of studies have focused on the impact of temperature and precipitation on distribution odonata (Hickling et al., 2005; Finch et al., 2006; Hassall, 2012). Temperature increments may encourage the development of odonata species ranges and lead to increments in local biodiversity in northern latitudes (Hassall and Thompson, 2008).

Latitudinal gradients in species richness are observed for a wide range of taxonomic groups (Gaston 2000). Spatial patterns in species richness can be described as the result of several mechanisms (Gaston and Blackburn 1990). Among the factors crucial for the 
impact on the species number of some area, the most dominant are: altitude (Rahbek 1995), energy availability (Gaston 2000), climate (Rohde, 1992), habitat heterogeneity (Rahbek and Graves 2000; Kerr 2001), and disturbance (Huston 1994).

No previous studies have addressed the effects of climate and habitat parameters on odonates in Serbia. In this study, factors that influence number of species in Serbia were examined. The effects of temperature, precipitation and altitude on the number of odonates species were investigated. So, the potential of odonates to serve as indicators of climate effects on freshwater systems of this region was evaluated.

\section{Materials and methods}

Serbia is situated in the Danube basin on the edge of the Mediterranean area, covering $88,361 \mathrm{~km}^{2}$ (Fig. 1). Serbia has rich genetic, species, and ecosystem diversity because of its geographic position (continental and Mediterranean influences, relief...). (Amidžić et al., 2014)

The paper analyzes the biodiversity of the odontas, both on the territory of the whole Republic of Serbia and at 6 different specific sites (Đukić, 2014). Collected data are average temperature, altitudes, and precipitation of regions from Republic Hydrometeorological Service of Serbia, Figures 2, 3 and 4.

The first site (1) is located in the north of Serbia, and this is the stream of the Tisa River. This site can be characterized by an altitude of up to $200 \mathrm{~m}$, mean annual temperatures around $15-25^{\circ} \mathrm{C}$, and precipitation (up to $600 \mathrm{~mm}$ per year). The second site (2) is a part of the stream and the mouth of the Sava and Danube rivers around Belgrade. The altitude is $400 \mathrm{~m}$ in this area. The mean annual temperature ranges from $20-25^{\circ} \mathrm{C}$. Precipitation is $600-700 \mathrm{~mm}$. The third site (3) is the stream of the Velika Morava, at an altitude of $400 \mathrm{~m}$. The mean annual temperature ranges from $10-15^{\circ} \mathrm{C}$. Precipitation is $600-700 \mathrm{~mm}$. Zlatibor is the fourth selected site (4) in the southeastern part of Serbia. This site has a significantly higher altitude, up to $1500 \mathrm{~m}$, mean annual temperature 10-15 ${ }^{\circ} \mathrm{C}$, and precipitation level $800-900 \mathrm{~mm}$ per year. The fifth site is the stream of the Južna Morava river (5), at an altitude of $400 \mathrm{~m}$, the mean annual temperature is $5-10{ }^{\circ} \mathrm{C}$, and the level of precipitation is $900-1000 \mathrm{~mm}$ per year. The last site is mount Golija (6), altitude above $1600 \mathrm{~m}$, mean annual temperature $10-15^{\circ} \mathrm{C}$, and precipitation level up to $600 \mathrm{~mm}$. 
Figure 1: Study area map

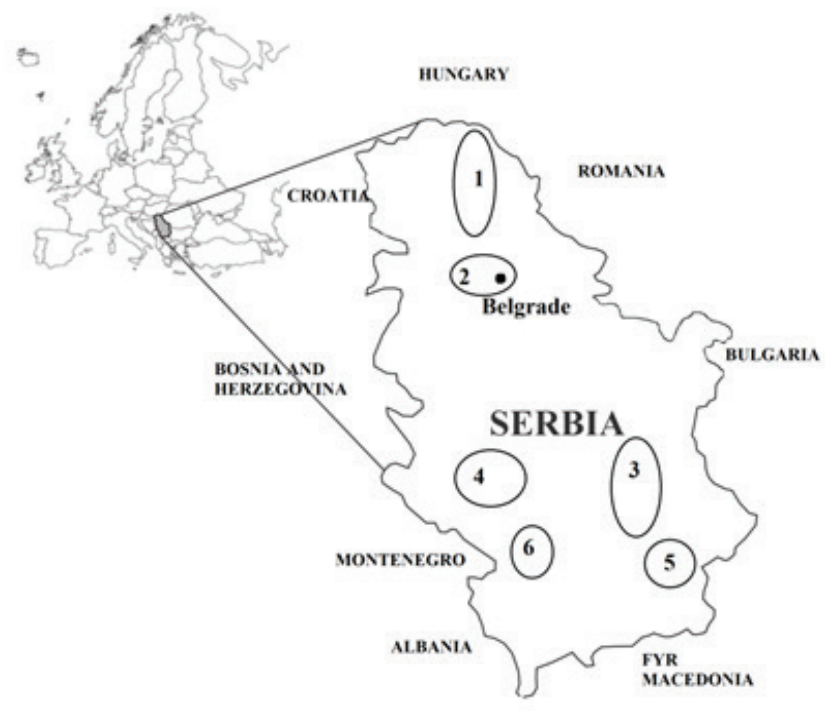

Source: Google maps and Alciphron - database of insects in Serbia (Odonata)

Data analysis. The Jaccard coefficient of similarity (Jt) determines the similarity of the fauna of the investigated sites and is calculated as

$$
l_{t}=\frac{m_{11}}{\left(m_{11}+m_{10}+m_{01}\right)}
$$

$\mathrm{t}$ - fauna of areas we compare, $\mathrm{m}_{11}$ - number of species common to both fauna we compare, $\mathrm{m}_{10}$ - number of species present in the first of the comparing fauna, $\mathrm{m}_{01}$ - number of species present in another fauna.

MLR model in Statistica. Multiple linear regression analyses are widely used in the analysis of data in ecology. It is widely used because it results in an equation that contains the effects of all variables that we want to consider in the description of a phenomenon or process (Boldina and Beninger 2016).

\section{Results and discussion}

The number of species registered by sites are as follows: $S 1=42, S 2=49, S 3=33$, $S 4=32, S 5=39, S 6=13$. Table 1 shows coefficient of similarity among observed sites in the form of a matrix.

Table 1. Jacarrd's coefficient between sites

\begin{tabular}{|c|c|c|c|c|c|c|}
\hline $\mathrm{J}_{\mathrm{r}}$ & 1 & 2 & 3 & 4 & 5 & 6 \\
\hline 1 & 1 & 0.70 & 0.46 & 0.48 & 0.56 & 0.15 \\
\hline 2 & & 1 & 0.61 & 0.57 & 0.74 & 0.20 \\
\hline 3 & & & 1 & 0.57 & 0.66 & 0.15 \\
\hline
\end{tabular}




\begin{tabular}{|c|l|l|l|l|c|c|}
\hline 4 & & & & 1 & 0.78 & 0.22 \\
\hline 5 & & & & & 1 & 0.21 \\
\hline 6 & & & & & & 1 \\
\hline
\end{tabular}

Source: Alciphron - database of insects in Serbia (Odonata) and RHS

The data required for model formation (MLR) are given in Table 2. Survey data indicate that the largest number of species has been identified in the $S 2$ area, at an altitude of $400 \mathrm{~m}$, with an average annual temperature of $22.5^{\circ} \mathrm{C}$ and an annual rainfall of $700 \mathrm{~mm}$. On the other hand, the smallest number of species is identified in the S6 area, with an altitude of $1800 \mathrm{~m}$ and an average annual temperature of $12.5^{\circ} \mathrm{C}$.

Table 2 Number of species by region and basic environmental parameters

\begin{tabular}{|c|c|c|c|c|}
\hline Region & $\mathrm{S}$ & $\mathrm{H}(\mathrm{m})$ & $\mathrm{t}\left({ }^{\circ} \mathrm{C}\right)$ & $\mathrm{p}(\mathrm{mm})$ \\
\hline 1 & 42 & 200 & 20 & 600 \\
\hline 2 & 48 & 400 & 22.5 & 700 \\
\hline 3 & 34 & 400 & 12.5 & 700 \\
\hline 4 & 32 & 1500 & 12.5 & 900 \\
\hline 5 & 39 & 400 & 7.5 & 1000 \\
\hline 6 & 13 & 1800 & 12.5 & 600 \\
\hline
\end{tabular}

Source: Alciphron - database of insects in Serbia (Odonata) and RHS

Correlation coefficients between altitude $(\mathrm{h})$, temperature $(\mathrm{t})$ and precipitation (prec.) are:
$\mathrm{r}(\mathrm{h}-\mathrm{t})=-0.33$
$r(h-p)=-0.03$
$r(t-p)=-0.63$

According the results, species occurrence was highest in Sava-Dunav site, followed by Tisa site. Odonates occurrence was lowest in the Golija site. In order to express the similarity of the fauna of the explored sites, the Jaccard coefficient was used and a high percentage of similarities was found among most of sites, with the exception of Golija. Based on the calculated correlations, Table 3, the inverse proportionality between the number of species and altitudes is found as the most dominant.

The resulting MLR model is shown in Table 3. The equation is given as follows:

$$
S(h, t, \text { per. })=\beta 0+\beta 1 \cdot h+\beta 2 \cdot t+\beta 3 \cdot \text { prec. }
$$

Table 3: MLR model of species number in dependence of altitude, temperature and precipitation

\begin{tabular}{|l|r|r|r|r|r|r|}
\hline & \multicolumn{1}{|c|}{ Beta } & St.err. of Beta & \multicolumn{1}{c|}{ B } & \multicolumn{1}{c|}{ St.err. of B } & \multicolumn{1}{c|}{$\mathrm{t}(2)$} & \multicolumn{1}{c|}{-level } \\
\hline Interception & & & -15.433 & 5.1553 & -2.993 & 0.0958 \\
\hline $\mathrm{h}$ & -0.5917 & 0.0488 & -0.010 & 0.0009 & -12.114 & 0.0067 \\
\hline $\mathrm{t}$ & 0.7097 & 0.0627 & 1.536 & 0.1358 & 11.309 & 0.0077 \\
\hline prec. & 0.6519 & 0.0592 & 0.048 & 0.0043 & 11.005 & 0.0081 \\
\hline
\end{tabular}

Source: Alciphron - database of insects in Serbia (Odonata) and RHS

$\mathrm{R}=0.99809045 \quad \mathrm{R} 2=0.99618454 \quad$ adj. $\mathrm{R} 2=0.99046135$

$\mathrm{F}(3,2)=174.06 \quad \mathrm{p}<0.00572 \quad$ St.err.of estim. $=1.1779$

Based on the MLR, Table 3, temperature is found as the most dominant factor that influence odonates diversity (the highest B value). 


\section{Conclusion}

Based on the results presented in the paper, it is possible to conclude the great importance of temperature on the diversity of the odonata in six observed sites. Increasing the number of species corresponds to the environment with higher temperature and lower altitude. The highest number of odonates species is found along the river flows in the plain area, while the smallest number of speciesis found on the mountainous areas. The MLR model shows the dependence of the number of species in some area, of an altitude, temperature and precipitation. The resulting model shows a high level of agreement with real values, $\mathrm{R}>0.99$.

\section{References}

Amidžić, L., Bartula, M., \& Cvetković, D. (2014). The state of biodiversity of Serbia. Natural Areas Journal, 34(2): 222-226

Arimoro, F.O., Nwadukwe, F.O., \& Mordi K.I. (2011). The influence of habitat and environmental water quality on the structure and composition of the adult aquatic insect fauna of the Ethiope River, Delta State, Nigeria. Tropical Zoology, 24(2):159_ 171.

Bried, J.T, \& Mazzacano, C.A. (2010). National review of state wildlife action plans for Odonata species of greatest conservation need. Insect Conserv Divers, 3(2): 61-71

Chapin, S.F., Zavaleta, E.S., \& Eviner, V.T. (2000). Consequences of changing biodiversity. Nature, 405: 234-242. doi:10.1038/35012241

Clausnitzer, V., Dijkstra, K.D.B., Koch, R., Boudot, J.P., Darwall, W.R.T., Kipping, J., Samraoui, B., Samways, M.J., Simaika, J.P., \& Suhling, F. (2012). Focus on African freshwaters: hotspots of dragonfly diversity and conservation concern. Front Ecol Environ, 10(3):129-134

Đukić, A. (Ed.) (2014). Alciphron-database of insects in Serbia (Odonata), HabiProt http:// habiprot.org.rs/, Retrieved 20.12.2018.

Finch, J.M., Samways, M.J., Hill, T.R., Piper, S.E., \& Taylor, S. (2006). Application of predictive distribution modelling to invertebrates: Odonata in South Africa. Biodivers Conserv, 15(13): 4239-4251

Franzese, P.P, Liu, G., \& Arico, S. (2019). Environmental accounting models and nature conservation strategies. Ecological Modelling, 397: 36-38

Gaston, K.J. (2000). Global patterns in biodiversity. Nature, 405:220-227. doi: $10.1038 / 35012228$

Gaston, K.J., \& Blackburn, T.M. (1990). Effects of scale and habitat on the relationship between regional distribution and local abundance. Oikos, 58:329-335. doi: $10.2307 / 3545224$

Hardersen, S. (2000). The role of behavioural ecology of damselflies in the use of fluctuating asymmetry as a bioindicator of water pollution. Ecological Entomology, 25:45-53

Hassall, C. (2012). Predicting the distributions of under-recorded Odonata using species distribution models. Insect Conserv Divers, 5(3):192-201 
Hassall, C., \& Thompson, D.J. (2008). The effects of environmental warming on Odonata: a review. Int J Odonatol, 11(2):131-153

Hickling, R., Roy, D.B., Hill, J.K., \& Thomas, C.D. (2005). A northward shift of range margins in British Odonata. Glob Change Biol, 11(3):502-506

Huston, M.A . (1994). Biological diversity: the coexistence of species in changing landscapes. Cambridge University Press, Cambridge

Kerr, J. (2001). Global biodiversity patterns: from description to understanding. Trends Ecol Evol, 16:424-425. doi:10.1016/S0169-5347(01)02226-1

McGeoch, M.A. (1998). The selection, testing and application of terrestrial insects as bioindicators. Biological Reviews, 73(2):181-201.

Oppel, S. (2006). Comparison of two Odonata communities from a natural and a modified rainforest in Papua New Guinea. International Journal of Odonatology, 9:89-102.

Rahbek, C. (1995). The elevation gradient of species richness: a uniform pattern? Ecography, 18:200-205. doi: 10.1111/j.1600-0587.1995.tb00341.x

Rahbek, C., \& Graves, G.R. (2000). Detection of macro-ecological patterns in South American hummingbirds is affected by spatial scale. Proc R Soc B Biol Sci, 267:22592265

Robinet, C., David, G., \& Jactel, H. (2019). Modeling the distances traveled by flying insects based on the combination of flight mill and mark-release-recapture experiments. Ecological Modelling, 402: 85-92

Rohde, K. (1992). Latitudinal gradients in species diversity: the search for the primary cause. Oikos, 65:514-527. doi:10.2307/3545569

Sahlen, G., \& Ekestubbe, K. (2001). Identification of dragonflies (Odonata) as indicators of general species richness in boreal forest lakes. Biodivers Conserv, 10(5):673-690

Samways, M.J., \& Steytler, N.S. (1996). Dragonfly (Odonata) distribution patterns in urban and forest landscapes, and recommendations for riparian management. Biological Conservation 78(3):279-288.

Silva, D., De Marco, \& P., Resende, D.C. (2010). Adult odonate abundance and community assemblage measures as indicators of stream ecological integrity: a case study. Ecological Indicators, 10(3):744-752.

Simaika, J.P., \& Samways, M.J. (2011). Comparative assessment of indices of freshwater habitat conditions using different invertebrate taxon sets. Ecological Indicators, 11(2):370-378.

Suhling, F., Sahlen, G., Martens, A., Marais, E., \& Schutte, C. (2006). Dragonfly assemblages in arid tropical environments: a case study from Western Namibia. Biodivers Conserv, 15(1):311-332

Williams, P.H., Margules, C.R., \& Hilbert, D.W. (2002). Data requirements and data sources for biodiversity priority area selection. J Biosci., 27:327-338

Republic Hydrometeorological Service of Serbia, Retrieved 20.12.2018. http://www. hidmet.gov.rs/eng/meteorologija/klimatologija.php 